\title{
Genetic Characterization of $R R S 1$, a Recessive Locus in Arabidopsis thaliana that Confers Resistance to the Bacterial Soilborne Pathogen Ralstonia solanacearum
}

\author{
Laurent Deslandes, ${ }^{1}$ Frédéric Pileur, ${ }^{1}$ Laurence Liaubet, ${ }^{1}$ Sylvie Camut, ${ }^{1}$ Canan Can, ${ }^{2}$ \\ Kevin Williams, ${ }^{2}$ Eric Holub, ${ }^{3}$ Jim Beynon, ${ }^{3}$ Matthieu Arlat, ${ }^{1}$ and Yves Marco ${ }^{1}$ \\ ${ }^{1}$ Laboratoire de Biologie Moléculaire des Relations Plantes-Microorganismes, CNRS-INRA, BP 27 \\ Auzeville, Castanet-Tolosan, France; ${ }^{2}$ Department of Biological Sciences, Wye College, University of \\ London, Wye, Kent, TN25 5AH, UK; ${ }^{3}$ Department of Plant Genetics and Biotechnology, Horticulture \\ Research International, Wellesbourne, Warwick, CV35 9EF, UK \\ Accepted 18 March 1998.
}

\begin{abstract}
The soilborne, vascular pathogen Ralstonia solanacearum, the causative agent of bacterial wilt, was shown to infect a range of Arabidopsis thaliana accessions. The pathogen was capable of infecting the Col-5 accession in an hrpdependent manner, following root inoculation. Elevated bacterial population levels were found in leaves of Col-5, 4 to 5 days after root inoculation by the GMI1000 strain. Bacteria were found predominantly in the xylem vessels and spread systemically throughout the plant. The Nd-1 accession of $A$. thaliana was resistant to the GMI1000 strain of $R$. solanacearum. Bacterial concentrations detected in leaves of $\mathrm{Nd}-1$, inoculated with an $\boldsymbol{h r p}^{+}$strain of $\boldsymbol{R}$. solanacearum, were only slightly higher than those detected in the susceptible accession, Col-5, following inoculation with a strain whose hrp gene cluster was deleted. Leaf inoculation of the GMI1000 strain on the resistant accession Nd-1 induced the formation of lesions in the older leaves of the rosette whereas the same strain of $R$. solanacearum provoked complete wilting of Col-5. Resistance to strain GMI1000 of $R$. solanacearum segregated as a simply inherited recessive trait in a genetic cross between Col-5 and Nd-1. F9 recombinant inbred lines generated between these two accessions were used to map a locus, $R R S 1$, that was the major determinant of resistance between restriction fragment length polymorphism markers mi83 and mi61 on chromosome V. This region of the $A$. thaliana genome is known to contain many other pathogen recognition capabilities.
\end{abstract}

Additional keywords: hrp genes, $R$ gene.

In plants, the outcome of many plant-pathogen interactions is determined by the presence or absence of complementary pairs of resistance $(R)$ genes in the host and avirulence ( $a v r)$ genes in

Corresponding author: Yves Marco, Laboratoire de Biologie Moléculaire des Relations Plantes-Microorganismes, CNRS-INRA, BP 27 Auzeville, Castanet-Tolosan, France; Telephone: +33-5-61-28-53-21; Fax: +33-5-61-28-51-60; E-mail: marco@toulouse.inra.fr the invading microorganism (Flor 1971). Resistance is believed to be the result of a direct or indirect interaction between the products of the $R$ gene and that of the corresponding avr gene (Keen 1990). The recent cloning of several plant disease $R$ genes and corresponding pathogen $a v r$ genes supports this genefor-gene model. AvrPto, the avirulence protein of Pseudomonas syringae pv. tomato, was shown, in the yeast two-hybrid system, to interact directly with the tomato Pto resistance protein, which codes for a cytoplasmic serine-threonine kinase (Tang et al. 1996; Scofield et al. 1996). The molecular characterization of a range of $R$ genes has led to the identification of several structural classes. The majority of $\mathrm{R}$ proteins contain a leucine rich region that can be associated with a nucleotide binding site or a serine-threonine kinase (reviewed by Bent 1996). The existence of common biochemical defense mechanisms is suggested by structural similarities found in $R$ gene products, identified from different plant species, that enable isolate-specific interactions with various pathogens.

Bacterial wilt, one of the most important bacterial diseases worldwide, is caused by Ralstonia solanacearum, previously named Pseudomonas solanacearum (Yabuuchi et al. 1995). This soilborne, vascular pathogen affects hundreds of different species such as tomato, tobacco, potato, banana, eggplant, and pepper, mainly in tropical and subtropical areas (Hayward 1991). Recently, this pathogen has also been detected in Western Europe (A. Trigalet, personal communication). This species has been classified into five races, each of which contains hundreds of different strains (Buddenhagen et al. 1962). The products of the hrp (hypersensitive response and pathogenicity) genes are required for eliciting disease on susceptible hosts and a hypersensitive response (HR), a rapid and localized death of plant cells in contact with the pathogen, on non-host or resistant plants. hrp gene products appear to play a key role as pathogenicity determinants of $R$. solanacearum (Van Gijsegem et al. 1995). Several putative $h r p$-encoded proteins of this bacterial pathogen share homology with proteins from the animal pathogens Yersinia and Shigella, and are assumed to be structural constituents of a secretion machinery required for the release of extracellular proteins (Van Gijsegem et al. 1993 and 1995). 
Therefore, it is not surprising that this cluster of genes controls the secretion of some extracellular proteins that are active on plants, such as PopA1, a protein inducing an HR-like response on tobacco and on certain genotypes of Petunia (Arlat et al. 1994). A wide variety of extracellular compounds, including copious amounts of the high-molecular-mass, acidic extracellular polysaccharide EPS I, also participate in the ability of $R$. solanacearum to colonize host plants and cause wilt symptoms by impairing water transport (Schell et al. 1994).

The most effective strategy for controlling bacterial wilt remains breeding for resistance but a simply inherited resistance has not yet been clearly demonstrated. In tomato, resistance to the pathogen is polygenic and several loci governing resistance to bacterial wilt have been identified (Thoquet et al. 1996a and 1996b). In that interaction, resistance was dependent on environmental factors, including the physiology of the plants, the climate, and the type of soil.

Arabidopsis thaliana has become a widely accepted model plant for the study of plant-pathogen interactions, allowing the identification of $R$ genes active against bacteria, viruses, fungi, oomycetes, and nematodes (Mauch-Mani and Slusarenko 1993; Crute et al. 1994; Adam and Somerville 1996; Sijmons et al. 1994; Kunkel 1996). In some cases the relevant $R$ genes have been cloned (Bent 1996). The nature of the pathogen, the limitations of available strategies for controlling the disease, and the economical and social importance of the crops affected by $R$. solanacearum, prompted us to test whether $A$. thaliana could be used to analyze the mechanisms of resistance to this soilborne bacterium. In this report, we describe the mapping of a locus, $R R S 1$, which was the major component of wilt resistance to $R$. solanacearum strain GM1000 in A. thaliana accession Nd-1, to an interval between restriction fragment length polymorphism (RFLP) markers mi83 and mi61 on chromosome V.

\section{RESULTS}

\section{A. thaliana accession Col-5 became wilted after root inoculation by strain GMI1000 of $\boldsymbol{R}$. solanacearum in an hrp-dependent manner.}

Three-week-old plants of $A$. thaliana accession Col-5 were inoculated by immersing the roots in a bacterial suspension of $R$. solanacearum strain GMI1000 and incubating at $25^{\circ} \mathrm{C}$. This temperature was shown to be optimal for development of wilt symptoms by this pathogen in A. thaliana. Wilting was first observed on older leaves 4 to 8 days after inoculation, leading to wilting of the entire plant, 3 to 5 days later (Fig. 1A). These results were obtained when the root tips were cut prior to immersion in the inoculum. When root tips were not cut prior to inoculation, wilting of the plants was observed over a longer period of time (4 to 12 days). $\Delta h r p$, a derivative of the wild-type strain GMI1000 carrying a deletion of the hrp gene cluster, inoculated under the same conditions, failed to induce any symptom development in Col-5 plants (data not shown).

Different races of $R$. solanacearum have been defined according to their host specificity (Buddenhagen et al. 1962; Lozano and Sequeira 1970). Strains belonging to these different races were tested for their ability to infect Col-5 plants. Several of the tested strains induced the wilt disease, as shown in Table 1 .
Strain GMI1557, a derivative of strain GMI1000 containing the $\beta$-glucuronidase (GUS) reporter gene under the control of a constitutive promoter (C. Etchebar and A. Trigalet, unpublished data), was used to study the mode of invasion of the susceptible accession by the bacteria following root inoculation. Extensive staining of inoculated roots suggested the presence of high bacterial populations. A transverse root section of a Col-5 plant inoculated with strain GMI1557 indicated that the bacteria were found in the intercellular spaces and in the xylem vessels (Fig. $1 \mathrm{~B})$. This suggested that the pathogen invaded the plant via the vascular system. Bacteria were also detected in A. thaliana leaves of infected Col-5 plants (data not shown). No GUS activity was detectable in roots inoculated with the $\Delta h r p$ strain containing the same construct, probably due to much lower bacterial population levels. Infrequently, however, localized GUS activity was visualized on root surfaces. Lateral sections revealed that the staining in this case was in a location similar to that observed with the wild-type strain.

\section{The $A$. thaliana accession Nd-1 failed to develop symptoms following inoculation with $R$. solanacearum strain GMI1000.}

Sixteen additional accessions (Ws- 1 , Ler-0, Ct-1, Ms-0, Tu1, Kas-1, Ge-1, Be-0, Sl-0, Po-1, C24, Nd-1, No-0, Tu-1, Bla10, and Kil-0) of $A$. thaliana were tested for natural variation in disease resistance to strain GMI1000 of $R$. solanacearum. Nd-1 and Ct-1 were the only accessions that did not develop wilting symptoms. Nd-1 was chosen as the resistant parent for the genetic studies described below because of the availability of a mapping population of Col-5 $\times \mathrm{Nd}-1$ recombinant inbred lines (Holub and Beynon 1997).

The response of Nd-1 plants to other $R$. solanacearum strains was tested. This accession demonstrated a higher level of wilt resistance than Col-5 to most strains tested (Table 1). No wilt symptoms were observed after inoculation of Nd-1 with strains AW1, GA4, GT4, and 0170, whereas all of these strains were pathogenic on accession Col-5. It is interesting to note that these geographically diverse $R$. solanacearum strains induced similar responses on Col-5 and Nd-1. Two strains, GT1 and Rd-15, induced wilting on both Col-5 and Nd-1, suggesting the existence of different $a v r$ or virulence genes in these strains.

\section{Bacterial multiplication in susceptible and resistant accessions.}

In order to verify that the wilting observed with the susceptible accession, Col-5, was not simply caused by a toxic compound synthesized by the pathogen, internal bacterial growth curves were carried out on the aerial parts of the plants following root inoculation. Bacterial multiplication was also monitored in Nd-1 plants that did not produce symptoms after inoculation with strain GMI1000. Similar inoculation experiments were carried out with the $\Delta h r p$ strain. The data (Fig. 2A) indicated that the bacteria multiplied in an almost linear fashion in the rosettes of the susceptible accession and reached very high concentrations 10 days after inoculation ( $10^{12}$ bacteria per $g$ of fresh weight). In contrast, the bacterial density in the resistant accession increased slowly, reaching a plateau ( $10^{7}$ bacteria per $g$ of fresh weight) 10 days after inoculation and remaining at that level thereafter. This concentration was higher than that observed $\left(10^{4}\right.$ to $10^{5}$ bacteria per $g$ 
of fresh weight) in resistant or susceptible accessions inoculated with the $\Delta h r p$ strain. These results indicated that the ability of the bacteria to multiply throughout the plant was an hrp-dependent process. The lack of symptoms in Nd-1 plants inoculated with the virulent strain was probably due to the bacteria only reaching low population levels. Bacteria were detected a few minutes after root inoculation in the leaves of the rosette. This observation can be explained by their passive
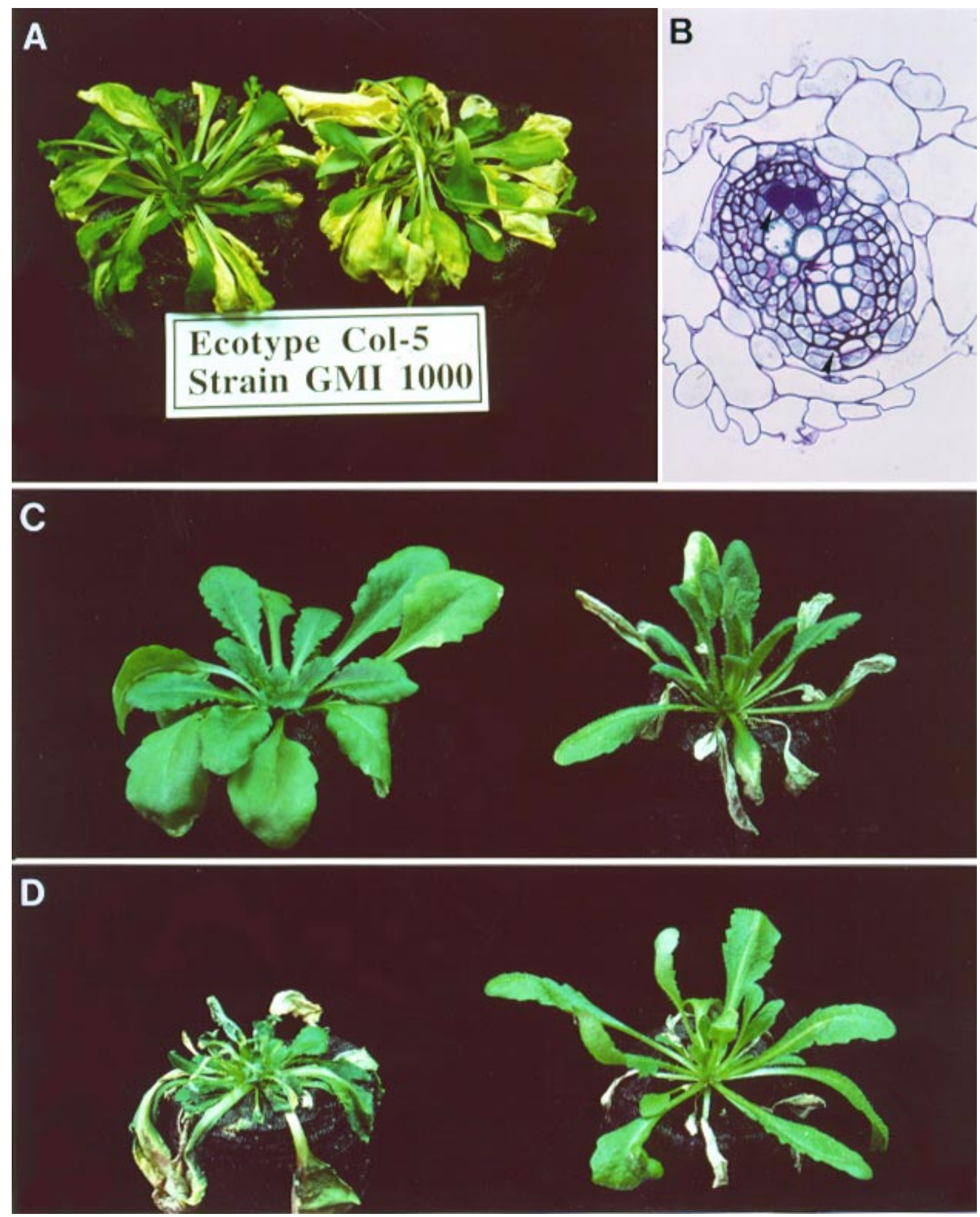

Fig. 1. A, Phenotype of susceptible Arabidopsis thaliana Col-5 plants, 10 days after root inoculation by the Ralstonia solanacearum GMI1000 strain. B, Cross section of A. thaliana Col-5 root infected with strain GMI1557, a derivative of strain GMI1000 of $R$. solanacearum expressing constitutively the uidA reporter gene of Escherichia coli. Staining due to $\beta$-glucuronidase (GUS) activity was detected in intercellular spaces and xylem vessels as indicated by arrows. C and D, Phenotype of susceptible Col-5 (left) and resistant Nd-1 (right) plants, 2 (C) and 10 (D) days after total infiltration by GMI1000 strain. 
absorption and rapid diffusion in the whole plant. However, their ability to multiply was dependent on the plant genotype and the bacterial strain used.

Inoculation by vacuum infiltration of whole Col-5 and Nd-1 plants with GMI1000 bacterial suspensions provoked the formation of necrotic regions that could extend to the whole affected leaf in older rosette leaves of Nd-1 plants, $48 \mathrm{~h}$ after inoculation. In contrast, no symptoms were visible on the susceptible accession infiltrated with the same bacterial strain at this stage (Fig. 1C). However, 6 to 10 days later, the susceptible plants wilted and died, while the resistant plants continued to grow and showed no evidence of wilting (Fig. 1D). The $\Delta h r p$ strain failed to induce wilting or necrotic lesions on either $A$. thaliana accession.

Bacterial population levels were estimated in leaves of Col5 and Nd-1 plants that had been vacuum infiltrated with the $\Delta h r p$ and GMI1000 strains. Ten days after inoculation, virulent bacteria multiplied in the leaf tissue and reached concentrations of up to $10^{11}$ to $10^{12}$ bacteria per $\mathrm{g}$ of fresh weight (Fig. 2B). In the resistant accession, a slight increase in the bacterial concentration was observed during the first 2 days followed by a decrease in the population levels. This decrease is probably due to bacterial death in necrotic leaves and/or to a dilution of the bacteria in growing tissues. In plants of both accessions inoculated by the $\Delta h r p$ strain, bacteria were able to multiply to a low extent and their concentration remained roughly constant throughout the experiment (around $10^{6}$ to $10^{7}$ bacteria per $g$ of fresh weight). It is interesting to note that, 17 days after inoculation, bacterial population levels were lower in Nd-1 plants inoculated by the GMI1000 strain $\left(10^{5}\right.$ to $10^{6}$ bacteria per $\mathrm{g}$ of fresh weight) than in $\Delta h r p$-inoculated Nd-1 or Col-5 plants, 8 days after inoculation.

\section{Genetic analysis of $R R S 1$.}

Accessions Col-5 and Nd-1 were crossed and the $\mathrm{F}_{1}$ plants were tested for their response to inoculation by GMI1000. All the tested plants (23 obtained from five independent crosses) developed the wilt disease after root inoculation. $F_{2}$ progeny were then tested for their reaction to strain GMI1000. Resistance to these bacteria segregated in a manner consistent with the existence of a single recessive gene in the $\mathrm{F}_{2}$ progeny $(810$ tested plants, 214 resistant:596 susceptible, $\chi^{2}=0.870$ for a $1: 3$ segregation, $P=0.36$ ). These results were confirmed by the phenotypic analysis of $F_{3}$ progeny from 22 resistant $F_{2}$ plants inoculated with strain GMI1000. All the tested plants were indeed found to be uniformly resistant to the pathogen. The resistance locus was designated RRS1 (recognition of $\underline{R}$. solanacearum).

In order to map RRS1, 161 individual lines of an $\mathrm{F}_{9}$ recombinant inbred population produced by a cross between Col-5 and Nd-1 (Holub and Beynon 1997) were tested for their response to strain GMI1000. Recombination analysis suggested that nga129, a marker on chromosome V, was linked to RRS1 (Table 2). No significant linkage was detected on the other chromosomes. Segregation of molecular markers in the inbred populations revealed linkage to a 49.1 centiMorgans (cM) interval on chromosome V (Fig. 3) between simple sequence length polymorphism (SSLP) loci nga76 and nga129. RRS1 mapped $15.1 \mathrm{cM}$ from ngal29. The use of further markers within this interval confirmed the location of RRS1 on chromosome $\mathrm{V}$ between mi61 and mi83, in an interval of $6.8 \mathrm{cM}$ (Fig. 3). RRS1 was mapped to a distance of $1.6 \mathrm{cM}$ from mi61. Table 3 shows mapping data for the key recombinant families that allowed the unambiguous positioning of RRS1 between the RFLPs detected by mi83 and mi61.

Of the $161 \mathrm{~F}_{9}$ families analyzed, 100 lines were resistant and 61 lines developed the wilt symptoms, a ratio of 1.64:1 $\left(\chi^{2}=9.45\right.$ for a $1: 1$ segregation, $\left.P=0.002\right)$. This ratio, in apparent contradiction to the results obtained with the $\mathrm{F}_{2}$ population, was, however, matched by the segregation of the Col-5 and Nd-1 genotypes for molecular markers mi83 and mi61, located between $n g a 76$ and ngal29 (Table 2). For example, although ngal29 and nga76 segregated 1.1:1 (Nd-1:Col-5), markers mi83 and mi61, which are tightly linked to RRS1, showed segregation ratios of 1.51:1 and 1.55:1 (Nd-1:Col-5), respectively. This would suggest the recombinant inbred lines are nonrandom or biased toward Nd-1 in their genetic segregation on the lower arm of chromosome V. Analysis with other molecular markers provided further confirmation of nonrandom segregation elsewhere in the genome in this mapping population (Table 2). For example, two markers on chromosome III, m249 and pAT389, segregated 1:1 and 1.6:1 in favor of Col-5, respectively. Therefore, the segregation of the resistance phenotype in this $\mathrm{F}_{9}$ population cannot be used reliably to generate a model for the number of genes involved in resistance. It is clear, however, from Table 3 that the nonrandom

Table 1. Responses of Arabidopsis thaliana Col-5 and Nd-1 plants root inoculated by the different Ralstonia solanacearum strains used in this study

\begin{tabular}{lllccll}
\hline & & & \multicolumn{2}{c}{ Response $^{\mathbf{a}}$} & \\
Strain of R. solanacerum & Host plant & Geographical origin & Col-5 & Nd-1 & Source or reference \\
\hline GMI1000 (race 1) & Tomato & French Guyana & S & R & Boucher et al. 1985 \\
AW1 (race 1) & Tomato & Alabama (U.S.) & S & R & Denny et al. 1988 \\
GA4 (race 1) & Eggplant & French West Indies & S & R & Prior et al. 1990 \\
GT4 (race 1) & Tomato & French West Indies & S & R & Prior et al. 1990 \\
0170 (race 1) & Tobacco & Qld-Australia & S & R & H. C. Hayward, University of Queensland, Brisbane, Australia \\
UW85 (race 1) & Tomato & Ontario, Canada & R & R & L. Sequeira, University of Wisconsin, Madison, WI \\
UW143 (race 1) & Tomato & Qld-Australia & R & R & Lozano and Sequeira 1970 \\
UW81 (race 3) & Potato & Columbia & R & R & Lozano and Sequeira 1970 \\
UW82 (race 3) & Potato & Columbia & R & R & L. Sequeira, University of Wisconsin, Madison, WI \\
BA4 (race 2) & Banana & Granada & R & R & P. Frossard, C.I.R.A.D., Montpellier, France \\
UW160 (race 2) & Plantain & Peru & R & R & Lozano and Sequeira 1970 \\
Rd15 (race nd) & Radish & Taiwan & S & S & S. T. Hsu, A.V.R.D.C., Tainan, Taiwan \\
GT1 (race 1) & Tomato & French West Indies & S & S & Prior et al. 1990 \\
\hline
\end{tabular}

${ }^{a}$ Ten plants of each ecotype were tested in two independent experiments. $\mathrm{R}$ and $\mathrm{S}$ indicate a resistant and susceptible phenotype, respectively. 
segregation within the $\mathrm{F}_{9}$ population of the markers most closely linked to RRS1 is in complete accord with the segregation observed with the phenotypic data.

Recombinant inbred lines containing recombination events between markers mi83 and mi61 responded similarly to inoculation by strains GMI1000, AW1, GA4, GT4, and 0170 (data not shown), suggesting that the gene(s) conferring resistance in Nd-1 and/or susceptibility in Col-5 to these strains is (are) either identical or physically closely linked.

\section{DISCUSSION}

Wilt diseases caused by the different races of $R$. solanacearum are of great interest because they affect hundreds of different plant species, including many crops of agronomic importance. $R$. solanacearum is a soilborne, vascular pathogen with a mode of invasion that differs from that of most bacterial pathogens. Although progress is being made on understanding the role of bacterial gene products involved in pathogenicity (Boucher et al. 1985; Denny et al. 1988; Schell et al. 1994), nothing is known about the plant gene products involved. In addition, little is known about genotype specificities of host $/ R$. solanacearum interactions (Carney and Denny
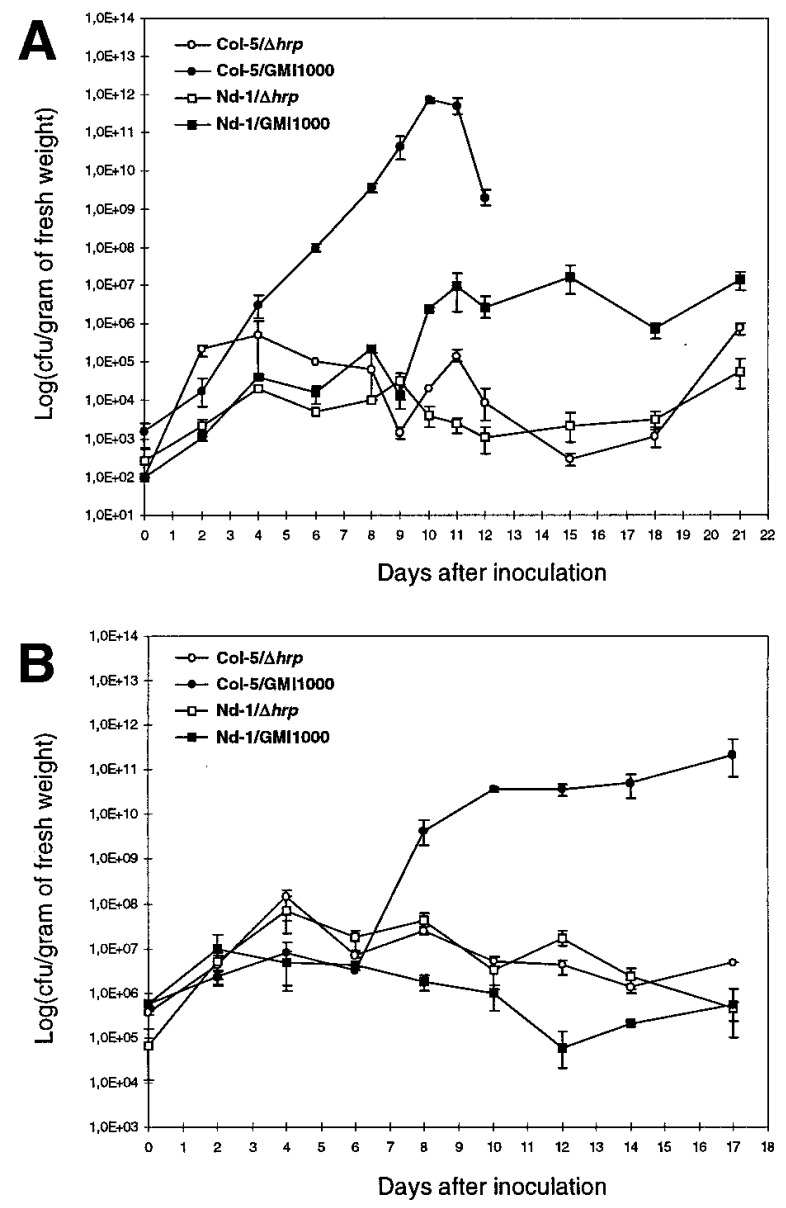

Fig. 2. Bacterial growth curves of GMI1000 and $\Delta h r p$ strains of Ralstonia solanacearum in leaves of Arabidopsis thaliana Col-5 and Nd-1 plants after (A) root inoculation and (B) total infiltration under vacuo. For each time point, triplicate assays were performed on three plants for each $A$. thaliana accession and bacterial strain.
1990). Resistance that has been described in tomato has been shown to be controlled by several loci (Aarons et al. 1993; Thoquet et al. 1996a and 1996b).

By employing $A$. thaliana as a model plant system for the study of plant-pathogen interactions, we have been able to define a plant locus involved in wilt resistance. Several $R$. solanacearum strains were shown to cause wilt disease on $A$. thaliana accessions. The genetic diversity of $A$. thaliana was used to identify an accession, $\mathrm{Nd}-1$, resistant to strain GMI1000 of $R$. solanacearum and an accession, Col-5, susceptible to GMI1000. When compared with Col-5, the accession Nd-1 demonstrated a higher general level of resistance to most strains tested.

An $R$. solanacearum strain, $\Delta h r p$, whose $h r p$ functions are deleted, behaved like a nonpathogen on A. thaliana, indicating that the integrity of this bacterial gene cluster was essential to the establishment of the wilt disease. The hrp genes, some of which are broadly conserved among plant and animal pathogens, are now considered to be involved in the synthesis of a type III protein secretion machinery in phytopathogenic bacteria (Van Gijsegem et al. 1995). In animal pathogens, this

Table 2. Percentage recombination between RRS1 and molecular markers spanning the five chromosomes of Arabidopsis thaliana in $\mathrm{F}_{9} \mathrm{Col}-5$ $\times \mathrm{Nd}-1$ recombinant inbred lines

\begin{tabular}{|c|c|c|c|c|c|}
\hline $\begin{array}{l}\text { Chromo- } \\
\text { some }\end{array}$ & Marker & Nd-1:Col-5 ${ }^{a}$ & Ratio $^{b}$ & $\begin{array}{l}\text { Recombi- } \\
\text { nant lines/ } \\
\text { total lines }\end{array}$ & $\begin{array}{c}\text { Recom- } \\
\text { bination } \\
(\%)\end{array}$ \\
\hline \multirow[t]{4}{*}{ I } & $N C C 1^{\mathrm{d}}$ & $80: 76$ & 1.05 & $80 / 135$ & 59.2 \\
\hline & $\mathrm{Y} 1001^{\mathrm{d}}$ & $73: 91$ & 0.8 & $75 / 147$ & 51.0 \\
\hline & $n g a 280^{\mathrm{e}}$ & $96: 74$ & 1.29 & $66 / 151$ & 43.7 \\
\hline & $G A P B^{\mathrm{d}}$ & $66: 91$ & 0.72 & $67 / 134$ & 50.0 \\
\hline \multirow[t]{3}{*}{ II } & $\mathrm{m} 246^{\mathrm{f}}$ & $48: 31$ & 1.54 & $29 / 73$ & 39.7 \\
\hline & $G P A l^{\mathrm{d}}$ & $31: 30$ & 1 & $32 / 58$ & 55.1 \\
\hline & ngal68 & $38: 41$ & 0.92 & $38 / 74$ & 51.3 \\
\hline \multirow[t]{4}{*}{ III } & $\mathrm{T} 44885^{\mathrm{f}}$ & $23: 30$ & 0.76 & $26 / 48$ & 54.1 \\
\hline & $\mathrm{gl}-1^{\mathrm{d}}$ & $50: 30$ & 1.66 & $33 / 75$ & 44.0 \\
\hline & $\mathrm{m} 249^{\mathrm{f}}$ & $44: 44$ & 1 & $27 / 78$ & 34.6 \\
\hline & $\mathrm{IC} \mathrm{LL}^{\mathrm{f}}$ & $49: 53$ & 0.92 & $35 / 93$ & 37.6 \\
\hline \multirow[t]{5}{*}{ IV } & $A G^{\mathrm{d}}$ & $28: 29$ & 0.96 & $24 / 55$ & 43.6 \\
\hline & $\mathrm{m} 557^{\mathrm{f}}$ & $25: 36$ & 0.69 & $30 / 56$ & 53.6 \\
\hline & $5 \mathrm{C} 3 \mathrm{~L}^{\mathrm{f}}$ & $26: 32$ & 0.81 & $24 / 53$ & 45.3 \\
\hline & g $3883^{d}$ & $34: 43$ & 0.79 & $38 / 73$ & 52.0 \\
\hline & b9 $9^{d}$ & $37: 38$ & 0.97 & $31 / 69$ & 44.9 \\
\hline \multirow[t]{7}{*}{ V } & $n g a 225^{\mathrm{e}}$ & $33: 43$ & 0.77 & $42 / 71$ & 59.1 \\
\hline & $n g a 76^{\mathrm{e}}$ & $73: 62$ & 1.17 & $41 / 135$ & 30.4 \\
\hline & $m i 83^{\mathrm{f}}$ & $97: 64$ & 1.51 & $13 / 161$ & 8.0 \\
\hline & RRS1 & 100:61 & 1.64 & $\ldots$ & $\ldots$ \\
\hline & $m i 61^{\mathrm{f}}$ & $98: 63$ & 1.55 & $6 / 161$ & 3.7 \\
\hline & nga129e & $71: 64$ & 1.1 & $25 / 135$ & 18.5 \\
\hline & $L F Y 3^{\mathrm{d}}$ & $55: 31$ & 1.77 & $20 / 78$ & 25.6 \\
\hline
\end{tabular}

${ }^{a}$ Each ratio represents the number of resistant plants versus the number of susceptible plants.

${ }^{b}$ The calculated ratio between the numbers in the previous column.

c The number of plants for which a recombination event was detected between a given marker and the RRS1 locus versus the total number of tested plants for both markers.

${ }^{\mathrm{d}}$ CAPS markers (Konieczny and Ausubel 1993) except g3883 and b9 (Dietrich et al. 1997) and Y1001 (C. Borhan and J. Beynon, unpublished data).

e Simple sequence length polymorphism markers (Bell and Ecker 1994).

${ }^{\mathrm{f}}$ Restriction fragment length polymorphism markers designated $\mathrm{m}$ (Chang et al. 1988), mi (Liu et al. 1996), others: T44885, EST clone of resistance gene RPM1 (Grant et al. 1995); 1C7L, end probe from yUP1C7 (P. Bittner-Eddy and J. Beynon, unpublished data); 5C3L, end probe from yUP5C3 (K. Williams and J. Beynon, unpublished data). yUP1C7 and yUP5C3 are YAC clones (Ecker 1990). 
pathway differs from other secretion pathways by its ability to deliver virulence proteins directly into host cells (Rosqvist et al. 1995). Proteins such as PopA1 and harpins are secreted by the Hrp pathway although the primary function of these proteins in disease development remains unclear (Alfano and Collmer 1996). Accumulating evidence suggests that products of some $a v r$ genes are directly transferred into host cells via this secretion pathway (Gopalan et al. 1996; Leister et al. 1996; Van den Ackerveken et al. 1996; Scofield et al. 1996; Tang et al. 1996). The requirement for the integrity of the hrp genes necessary to the establishment of either the susceptible or the resistant interactions in the $R$. solanacearum/A. thaliana pathosystem may imply a mechanism of interaction in this wilting disease similar to that described in other plant/bacterial pathosystems.

The mode of invasion of $R$. solanacearum has been described previously, particularly during wilt disease development on tomato (Schmit 1978; Vasse et al. 1995). The bacteria penetrate the roots at root tips, or at sites of secondary root emergence, progress to the xylem, and then invade the whole plant systemically. Our data indicated that, in the susceptible A. thaliana accession Col-5, the result of invasion was similar to that in tomato, and bacteria were found predominantly in the xylem vessels and in the intercellular spaces. In contrast to Col-5, in roots of the resistant Nd-1 plants inoculated with strain GMI1000, lower bacterial densities did not allow the detection of the pathogen by GUS activity, except in some rare instances where localized elevated levels of bacteria allowed their visualization in the same location as in susceptible plants. High bacterial populations $\left(10^{12}\right.$ per $\mathrm{g}$ of fresh weight $)$ were present in the leaves of the Col-5 accession after root inoculation by GMI1000, illustrating the ability of the patho-

\section{Chromosome V}

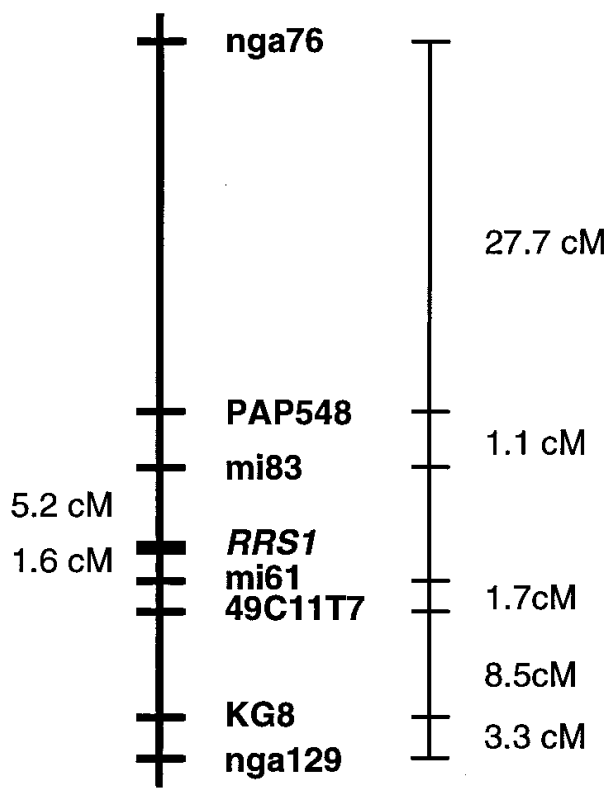

Fig. 3. Resistance locus, RRS1, was positioned between mi83 and mi61 restriction fragment length polymorphism markers on chromosome $\mathrm{V}$. Genetic distances between these markers and RRS1 locus are indicated. $\mathrm{cM}=$ centiMorgans. gen to multiply in the infected tissues. In Nd-1, bacteria also multiplied in the aerial parts of the plant, but were present at much lower concentrations (around $10^{7}$ per $g$ of fresh weight) than in Col-5. The $\Delta h r p$ mutant was capable of multiplying only to relatively low levels $\left(10^{4}\right.$ to $10^{5}$ bacteria per $\mathrm{g}$ of fresh weight) in both accessions.

When entire Nd-1 plants were infiltrated with strain GMI1000, a collapse of the older leaves of the rosette, caused by the rapid formation of necrotic lesions, was observed 24 to $48 \mathrm{~h}$ after inoculation. This cell death occurred earlier than the appearance of symptoms in Col-5 infiltrated with the same $R$. solanacearum strain. In the latter case, chlorotic lesions appeared later ( 72 to $96 \mathrm{~h}$ ) and the complete wilting of the leaves was observed 10 to 15 days after inoculation. These observations indicated that the differential responses of Col-5 and Nd1 accessions to strain GMI1000 were not dependent on the inoculation procedure. Indeed, GMI1000 bacteria delivered directly in the leaves of $\mathrm{Nd}-1$ remained at concentrations much lower than those observed in the susceptible accession. These observations also suggested that strain GMI1000 may induce an HR in the resistant accession. However, our knowledge of the pathogenicity determinants of $R$. solanacearum remains limited. The observed lesions in the older leaves of

Table 3. Mapping data for key recombinants that allowed the unambiguous positioning of the RRS1 locus ${ }^{\mathrm{a}}$

\begin{tabular}{|c|c|c|c|c|c|c|}
\hline Lines (no.) & nga76 & mi83 & RRS1 & mi61 & nga129 & $\%^{b}$ \\
\hline 43 & $\mathrm{R}$ & $\mathrm{R}$ & $\mathrm{R}$ & $\mathrm{R}$ & $\mathrm{R}$ & 26.7 \\
\hline 10 & $\mathrm{R}$ & $\mathrm{R}$ & $\mathrm{R}$ & $\mathrm{R}$ & $\mathrm{S}$ & 6.2 \\
\hline 2 & $\mathrm{R}$ & $\mathrm{R}$ & $\mathrm{R}$ & $\mathrm{S}$ & $\mathrm{S}$ & 1.2 \\
\hline 1 & $\mathrm{R}$ & $\mathrm{R}$ & $\mathrm{S}$ & $S$ & $S$ & 0.6 \\
\hline 13 & $\mathrm{R}$ & $S$ & $\mathrm{~S}$ & $S$ & $S$ & 8.1 \\
\hline 29 & $\mathrm{~S}$ & $\mathrm{~S}$ & $\mathrm{~S}$ & $\mathrm{~S}$ & $\mathrm{~S}$ & 18.0 \\
\hline 5 & $\mathrm{~S}$ & $\mathrm{~S}$ & $\mathrm{~S}$ & $\mathrm{~S}$ & $\mathrm{R}$ & 3.1 \\
\hline 3 & $\mathrm{~S}$ & $\mathrm{~S}$ & $\mathrm{R}$ & $\mathrm{R}$ & $\mathrm{R}$ & 1.9 \\
\hline 15 & $\mathrm{~S}$ & $\mathrm{R}$ & $\mathrm{R}$ & $\mathrm{R}$ & $\mathrm{R}$ & 9.3 \\
\hline 3 & $\mathrm{~S}$ & $\mathrm{R}$ & $\mathrm{R}$ & $\mathrm{R}$ & $\mathrm{S}$ & 1.9 \\
\hline 3 & $\mathrm{R}$ & $\mathrm{S}$ & $\mathrm{S}$ & $\mathrm{S}$ & $\mathrm{R}$ & 1.9 \\
\hline 3 & $S$ & $\mathrm{R}$ & $S$ & $S$ & $S$ & 1.9 \\
\hline 1 & $\mathrm{~S}$ & $\mathrm{R}$ & $\mathrm{R}$ & $\mathrm{S}$ & $\mathrm{R}$ & 0.6 \\
\hline 1 & $\mathrm{~S}$ & $\mathrm{R}$ & $\mathrm{R}$ & $\mathrm{S}$ & $\mathrm{S}$ & 0.6 \\
\hline 1 & $\mathrm{~S}$ & $\mathrm{~S}$ & $\mathrm{R}$ & $\mathrm{R}$ & $\mathrm{S}$ & 0.6 \\
\hline 1 & $\mathrm{R}$ & $S$ & $\mathrm{R}$ & $\mathrm{R}$ & $\mathrm{R}$ & 0.6 \\
\hline 1 & $\mathrm{~S}$ & $\mathrm{R}$ & $S$ & $\mathrm{R}$ & $S$ & 0.6 \\
\hline 17 & $\mathrm{ND}^{\mathrm{c}}$ & $\mathrm{R}$ & $\mathrm{R}$ & $\mathrm{R}$ & ND & 10.6 \\
\hline 5 & $\mathrm{ND}$ & $S$ & $\mathrm{~S}$ & $\mathrm{~S}$ & $\mathrm{ND}$ & 3.1 \\
\hline 1 & $\mathrm{ND}$ & $\mathrm{S}$ & $\mathrm{S}$ & $\mathrm{R}$ & ND & 0.6 \\
\hline 3 & $\mathrm{ND}$ & $\mathrm{S}$ & $\mathrm{R}$ & $\mathrm{R}$ & ND & 1.9 \\
\hline
\end{tabular}

a The number of lines with the same genotype for the nga76, mi83, mi61, and nga129 markers is indicated on the left. $\mathrm{R}$ and $\mathrm{S}$ indicate Nd-1 and Col-5 genotypes, respectively.

b Percentage of lines with a given genotype versus total number of tested lines.

c Not determined. 
the resistant accession might be caused by some bacterial necrotizing factor(s) such as PopA1 (Arlat et al. 1994) or others not yet identified and, therefore, be unlinked to the HR.

With the identification of $A$. thaliana lines exhibiting a differential response, with respect to wilting following inoculation with strain GMI1000, the genetic basis of resistance to this pathogen could be evaluated. A 1:3 segregation ratio (resistant: susceptible) was observed in $\mathrm{F}_{2}$ populations obtained from crosses between Col-5 and $\mathrm{Nd}-1$, suggesting that resistance to $R$. solanacearum was conferred by a single recessive gene. Recessive genes have been implicated in the resistance of plants to a wide range of pathogens including the fungi Erysiphe cichoracearum (Adam and Somerville 1996) and Erysiphe graminis (Wolter et al. 1993); the oomycete Albugo candida (Holub et al. 1995), and viruses (Fraser 1990). Interactions in which disease resistance is recessive might be caused by the absence or alteration of a plant component essential for pathogen growth or propagation, thus conferring a resistant phenotype (Fraser 1990). Alternatively, the plant component may correspond to a target of some pathogenicity determinants. In such cases, the dominant allele providing this component could be considered to be a susceptibility factor. This type of resistance could have been developed by plants to combat pathogens that depend strictly on the host biochemical machinery to multiply and/or invade the plant. In the case of $R$. solanacearum, work in our laboratory suggests that the synthesis of some pathogenicity determinants might be under the control of plant factors (Marenda et al. 1998). In the case of the recessive mlo resistance alleles of the Mlo locus controlling a non-race-specific resistance response to the fungus Erysiphe graminis f. sp. hordei, it has been proposed that the Mlo allele may function as a negative regulator of the defense response (Wolter et al. 1993). The Mlo protein may also have a negative control function in leaf cell death since mlo plants exhibit a spontaneous cell death phenotype under pathogenfree or even axenic conditions. The recent cloning of the barley Mlo gene (Büschges et al. 1997), which encodes a putative membrane-anchored protein with structural features differing from those of other resistance proteins isolated so far, should provide further insight into the function of this novel resistance element.

Recombinant inbred lines generated between Col-5 and Nd1 were used to map the RRS1 locus. A discrepancy was recorded between the observed segregation ratio of 1.64:1 (resistant:susceptible) and the expected ratio of 1:1 based on $\mathrm{F}_{2}$ data. This was explained by a biasing of the segregation of the flanking molecular markers, mi83 and mi61, to a similar extent (1.51:1 and 1.55:1, respectively) in favor of the resistant parent, Nd-1. This indicated that the segregation of the two parental chromosomes in the region of RRS1 was nonrandom. Such a selection for the presence of a given parental DNA in distinct regions of the A. thaliana genome has already been reported (Lister and Dean 1993). Key recombinant families demonstrated unambiguously that the RRS1 locus was located on chromosome $\mathrm{V}$ between the molecular markers mi83 and mi61. It is interesting to note that several loci conferring tolerance to different pathogens such as viruses, oomycetes, and bacteria have recently been localized in this region of chromosome V (Lee et al 1996; Holub 1997).

Recombinant inbred lines containing recombination events between markers mi83 and mi61 responded similarly to in- oculation by various $R$. solanacearum strains GMI1000, AW1, GA4, GT4, and 0170. Although the genetic bases of resistance to these different strains have not been established, this observation suggested that the gene(s) conferring resistance in Nd-1 and/or susceptibility in Col-5 is (are) either identical or physically closely linked.

In this study, we have demonstrated that some $A$. thaliana accessions develop wilt disease upon infection by a wide range of $R$. solanacearum strains. Our data also indicate that the mode of invasion of this crucifer, through the vascular system, as well as bacterial multiplication were similar to that described for its "natural" hosts, such as solanaceous plants. The identification of resistant and susceptible interactions between $R$. solanacearum and A. thaliana allowed the use of $\mathrm{F}_{9}$ recombinant inbred lines from a cross between Col-5 and Nd-1 to reveal the existence of a single, recessive resistance locus, $R R S 1$, located on chromosome V of Nd-1. Further work is now underway to clone the RRS1 locus by chromosome walking. This study should reveal information on the structure and function of RRS1. In addition, the detailed analysis of this entire region would reveal the interrelationship of the complex of $R$ genes lying in the multiple resistance complex $\mathrm{J}$ region of A. thaliana (Botella et al. 1997).

\section{MATERIAL AND METHODS}

\section{Bacterial strains.}

The $R$. solanacearum strains GMI1000, AW1, GA4, GT4, GT1, UW81, UW82, UW160, BA4, UW85, UW143, 0170, and $\mathrm{Rd} 15$ are wild-type strains isolated from a variety of plant species (Table 1). A derivative of the GMI1000 isolate, $\Delta h r p$, was deleted from the $h r p$ cluster and was replaced by an $\Omega$ cassette (spectinomycin ${ }^{\mathrm{r}} /$ streptomycin $^{\mathrm{r}}$ ) (Prentki and Krish 1984). This mutant causes no apparent HR on tobacco leaves and no disease symptom on inoculated tomato (C. A. Boucher, unpublished data). The strain GMI1557 was derived from the strain GMI1000 by insertion of a Tn5-gusA3 transposon (Sharma and Signer 1990). This strain, which was not affected in its pathogenicity, was kindly provided by A. Trigalet (C. Etchebar and A. Trigalet, unpublished data). All these strains were grown at $28^{\circ} \mathrm{C}$ in $\mathrm{B}$ broth or BGT solid medium (Boucher et al. 1985) and stored at $-80^{\circ} \mathrm{C}$.

\section{A. thaliana accessions and bacterial inoculations.}

A. thaliana accessions Col-0 and Col-5 (a glabrous derivative of Col-0 used for the generation of the recombinant inbred lines) were used in this study. No difference due to the presence or absence of trichomes was observed upon inoculation with the different $R$. solanacearum strains.

A. thaliana seeds were sterilized for $20 \mathrm{~min}$ with a $12 \%$ sodium hypochlorite solution, washed several times with sterile water and sown on MS medium (Murashige and Skoog 1962). Plantlets grown for 8 days at $20^{\circ} \mathrm{C}$ in a growth chamber were then transferred to Jiffy pots (Jiffy France, Lyon, France) and grown for 3 weeks in short day conditions $(10 \mathrm{~h} / 14 \mathrm{~h}$ light/dark) under constant light at $500 \mu \mathrm{E} \mathrm{s}^{-1} \mathrm{~m}^{-2}$.

Root inoculations were performed according to the following protocol: approximately $2 \mathrm{~cm}$ was cut from the bottom of the Jiffy pot and the exposed roots of the plants were immersed for $3 \mathrm{~min}$ in a suspension containing $10^{8}$ bacteria per $\mathrm{ml}$. The plants were then transferred to a growth chamber at $25^{\circ} \mathrm{C}(16 \mathrm{~h} / 8 \mathrm{~h}$ 
light/dark, constant light at $500 \mu \mathrm{E} \mathrm{s}^{-1} \mathrm{~m}^{-2}$ ) until symptoms appeared. Alternatively, plants were infiltrated under vacuo for 2 min by immersing the whole plant in the Jiffy pot in a bacterial suspension containing $10^{7}$ bacteria per $\mathrm{ml}$. The plants were transferred to $25^{\circ} \mathrm{C}$ as described previously.

One hundred and sixty-one $\mathrm{F}_{9}$ recombinant inbred lines, from a cross between $A$. thaliana accessions Col-5 $\times$ Nd-1, were tested for their response to the pathogen after root inoculation of nine plants, in two independent experiments.

The resistant or susceptible score was determined according to the percentage of wilted leaves on each individual inoculated plant: $100 \%$ of wilted leaves characterized a susceptible phenotype whereas a resistant phenotype was defined by the complete absence of wilting symptom. No intermediate phenotype was observed on the $\mathrm{F}_{2}$ progeny or on the recombinant inbred lines inoculated with the GMI1000 strain.

\section{Bacterial internal growth curves.}

The aerial parts of three plants inoculated with the GMI1000 or the $\Delta h r p$ strain of $R$. solanacearum were weighed, sterilized with $250 \mathrm{ml}$ of $70 \%$ ethanol for $3 \mathrm{~min}$, rinsed three times in sterile water, and ground in a mortar after addition of sterile water $(2.0 \mathrm{ml}$ per $\mathrm{g}$ of fresh weight). Various dilutions of the ground material were then performed with sterile water and the bacteria spread on petri plates containing solid BGT medium with the appropriate antibiotics (GMI1000 strain: rifampicin, $50 \mu \mathrm{g} / \mathrm{ml} ; \Delta h r p$ strain: streptomycin, 40 $\mu \mathrm{g} / \mathrm{ml}$ ) and grown at $30^{\circ} \mathrm{C}$. For each time point, triplicate assays were performed for each bacterial strain and A. thaliana accession. The same protocol was followed for root and leaf inoculations.

\section{Light microscopy protocol.}

Plants were root inoculated with the GMI1557 strain carrying the uidA gene from Escherichia coli fused to a constitutive promoter (C. Etchebar and A. Trigalet, unpublished data). At the appearance of the first wilting symptoms, plants were infiltrated under vacuo for $10 \mathrm{~min}$ in a solution containing 0.2 $\mathrm{M} \mathrm{NaPO}_{4}, \mathrm{pH} 7,0.1 \mathrm{M} \mathrm{K}_{3} \mathrm{Fe}(\mathrm{CN})_{6}, 0.1 \mathrm{M} \mathrm{K}_{4} \mathrm{Fe}(\mathrm{CN})_{6}, 0.5 \mathrm{M}$ $\mathrm{Na}_{2}$ EDTA and X-Gluc (5-bromo-4-chloro-3-indolyl- $\beta$-Dglucuronide; Clontech, Palo Alto, CA). Infiltrated samples were incubated overnight at $37^{\circ} \mathrm{C}$. They were then fixed in $0.3 \%$ formaldehyde, $50 \mathrm{mM} \mathrm{NaPO}_{4}$ buffer $\mathrm{pH} 7.0$ and stored in $70 \%$ ethanol. Root sections were obtained as described by Vasse et al. (1995).

\section{DNA extractions and Southern hybridizations.}

DNA was extracted from leaf tissue according to the protocol of Saghai-Maroof et al. (1984). After digestion with the appropriate restriction enzymes, separation of the DNA fragments was carried out on $0.8 \%$ agarose gels for $16 \mathrm{~h}$. Transfer to Hybond- $\mathrm{N}^{+}$membranes (Amersham, Buckinghamshire, UK) was performed according to the manufacturer's instructions, with 0.4 $\mathrm{M} \mathrm{NaOH}$ overnight. Membranes were then washed with $5 \times$ $\mathrm{SSC}(1 \times \mathrm{SSC}$ is $0.15 \mathrm{M} \mathrm{NaCl}$ plus $0.015 \mathrm{M}$ sodium citrate), UV treated (312 $\mathrm{nm}$ for $3 \mathrm{~min}$ ), and prehybridized for at least $4 \mathrm{~h}$ at $65^{\circ} \mathrm{C}$ in hybridization buffer (6× SSC, $5 \times$ Denhardt's, $100 \mu \mathrm{g}$ of single-stranded calf thymus DNA per $\mathrm{ml}$ and $0.5 \%$ sodium dodecyl sulfate [SDS] [wt/ vol]). The DNA inserts corresponding to the various probes used in this study were randomly labeled with $\left[\alpha^{32} \mathrm{P}\right] \mathrm{dCTP}$ (Pharmacia Biotechnologies, Buckingham- shire, UK). The heat-denatured labeled probes were added and the membranes incubated overnight at $65^{\circ} \mathrm{C}$. They were then washed in $500 \mathrm{ml}$ of $2 \times \mathrm{SSC}, 1 \% \mathrm{SDS}(\mathrm{wt} / \mathrm{vol})$ at room temperature for $30 \mathrm{~min}$ and then in $500 \mathrm{ml}$ of $0.1 \times \mathrm{SSC}, 0.1 \%$ SDS (wt/vol) for $15 \mathrm{~min}$ at $42^{\circ} \mathrm{C}$. Autoradiography was carried out at $-70^{\circ} \mathrm{C}$ for 1 to 3 days.

\section{SSLP and RFLP markers.}

The SSLP markers nga76 and ngal29 (Bell and Ecker 1994), the RFLP markers PAP548, mi83, mi61, 49C11T7, and $\mathrm{KG} 8$, as well as most of the markers used in Table 2, were obtained from the Arabidopsis Biological Resource Center (Columbus, OH). Strains carrying the plasmid clones were grown with the appropriate antibiotic. Plasmid DNA were purified with Qiagen columns according to the manufacturer's protocol (Qiagen, Chatsworth, CA). Five micrograms of DNA from the parental lines Col-5 and Nd-1 was digested with 36 different restriction enzymes and treated as described above. The transferred DNAs were subsequently hybridized with the various labeled probes as described above. The genetic map was constructed with the JoinMap Program (Stam 1993).

\section{ACKNOWLEDGMENTS}

We wish to thank André Trigalet for the $R$. solanacearum strains carrying the GUS reporter gene. We also thank the Ohio State University Arabidopsis Biological Resource for providing most of the RFLP probes mentioned in this study. Work at Horticulture Research International is funded by the Biotechnology and Biological Sciences Research Council.

\section{LITERATURE CITED}

Aarons, S. R., Danesh, D., and Young, N. D. 1993. DNA genetic marker mapping of genes for bacterial wilt resistance in tomato. Pages 170175 in: Bacterial Wilt. ACIAR Proc. No. 45. G. L. Hartman and A. C. Hayward, eds. Watson Ferguson, Brisbane, Australia.

Adam, L., and Somerville, S. C. 1996. Genetic characterization of five powdery mildew disease resistance loci in Arabidopsis. Plant J. 9: 341-356.

Alfano, J. R., and Collmer, A. 1996. Bacterial pathogens in plants: Life up against the wall. Plant Cell 8:1683-1698.

Arlat, M., Van Gijsegem, F., Huet, J. C., Pernollet, J. C., and Boucher, C. A. 1994. PopA1, a protein which induces a hypersensitivity-like response on specific Petunia genotypes, is secreted via the Hrp pathway of Pseudomonas solanacearum. EMBO J. 13:543-553.

Bell, C. J., and Ecker, J. R. 1994. Assignment of 30 microsatellite loci to the linkage map of Arabidopsis. Genomics 19:137-144.

Bent, A. F. 1996. Plant disease resistance genes: Function meets structure. Plant Cell 8:1757-1771.

Botella, M. A., Coleman, M. J., Hughes, D. E., Nishimura, M. T., Jones, J. D. G., and Somerville, S. C. 1997. Map positions of 47 Arabidopsis sequences with sequence similarity to disease resistance genes. Plant J. 12:1197-1211.

Boucher, C. A., Barberis, P. A., Trigalet, A. P., and Demery, D. A. 1985. Transposon mutagenesis of Pseudomonas solanacearum: Isolation of Tn5-induced avirulent mutants. J. Gen. Microbiol. 131:2449-2457.

Buddenhagen, I., Sequeira, L., and Kelman, A. 1962. Designation of races in Pseudomonas solanacearum. Phytopathology 52:726.

Büschges, R., Hollricher, K., Panstruga, R., Simons, G., Wolter, M., Friters, A., van Daelen, R., van der Lee, T., Diergaarde, P., Groenendijk, J., Töpsch, S., Vos, P., Salamini, F., and Schulze-Lefert, P. 1997. The barley Mlo gene: A novel control element of plant pathogen resistance. Cell 88:695-705.

Carney, B. F., and Denny, T. P. 1990. A cloned avirulence gene from Pseudomonas solanacearum determines incompatibility on Nicotiana tabacum at the host species level. J. Bacteriol. 172:4836-4843.

Chang, C., Bowman, J. L., DeJohn, A. W., Lander, E. S., and Meyerowitz, E. M. 1988. Restriction fragment length polymorphism linkage 
map for Arabidopsis thaliana. Proc. Natl. Acad. Sci. USA 85:68566880.

Crute, I., Beynon, J., Dangl, J., Holub, E., Mauch-Mani, B., Slusarenko, A., Staskawicz, B., and Ausubel, F. 1994. Microbial pathogenesis of Arabidopsis. Pages 705-748 in: Arabidopsis. E. M. Meyerowitz and C. R. Sommerville, eds. Cold Spring Harbor Laboratory, Cold Spring Harbor, NY.

Denny, T. P., Makini, F. W., and Brumbley, S. M. 1988. Characterization of Pseudomonas solanacearum Tn5 mutants deficient in extracellular polysaccharide. Mol. Plant-Microbe Interact. 1:215-223.

Dietrich, R. A., Richberg, M. A., Schmidt, R., Dean, C., and Dangl, J. L. 1997. A novel zinc finger protein is encoded by the Arabidopsis LSDI gene and functions as a negative regulator of plant cell death. Cell 88: 685-694.

Ecker, J. 1990. PFGE and YAC analysis of the Arabidopsis genome. Methods: A Companion to Methods in Enzymology 1:186-194.

Flor, H. H. 1971. Current status of the gene for gene concept. Annu. Rev. Phytopathol. 9:275-296.

Fraser, R. S. S. 1990. The genetics of resistance to plant viruses. Annu. Rev. Phytopathol. 28:179-200.

Gopalan, S., Bauer, D. W., Alfano, J. R., Loniello, A. O., He, S. Y., and Collmer, A. 1996. Expression of the Pseudomonas syringae avirulence protein AvrB in plant cells alleviates its dependence on the hypersensitive response and pathogenicity (Hrp) secretion system in eliciting genotype-specific hypersensitive cell death. Plant Cell 8: 1095-1105.

Grant, M. R., Godiard, L., Straube, E., Ashfield, T., Lewald, J., Sattler, A., Innes, R.W., and Dangl, J. L. 1995. Structure of the Arabidopsis $R P M 1$ gene enabling dual specificity disease resistance. Science 269: 843-846

Hayward, H. C. 1991. Biology and epidemiology of bacterial wilt caused by Pseudomonas solanacearum. Annu. Rev. Phytopathol. 29:65-87.

Holub, E. B. 1997. Organization of resistance genes in Arabidopsis. Pages 5-26 in: The Gene-for-Gene Relationship in Plant-Parasite Interactions. I. R. Crute, E. B. Holub, and J. J. Burdon, eds. CAB Int. Wallingford, UK

Holub, E. B., and Beynon J. L. 1997. Symbiology of mouse-ear cress (Arabidopsis thaliana) and oomycetes. Adv. Bot. Res. 24:227-273

Holub, E. B., Brose, E., Tör, M., Clay, C., Crute, I. R., and Beynon, J. L. 1995. Phenotypic and genotypic variation in the interaction between Arabidopsis thaliana and Albugo candida. Mol. Plant-Microbe Interact. 8:916-928.

Keen, N. T. 1990. Gene-for-gene complementarity in plant-pathogen interactions. Annu. Rev. Genet. 24:447-463.

Konieczy, A., and Ausubel, F. M. 1993. A procedure for mapping Arabidopsis mutations using co-dominant ecotype-specific PCRbased markers. Plant J. 4:403-410.

Kunkel, B. N. 1996. A useful weed put to work : genetic analysis of disease resistance in Arabidopsis thaliana. Trends Genet. 12:63-69.

Lee, J.-M., Hartman, G. L., Domier, L. L., and Bent, A. F. 1996. Identification and map location of TTR1, a single locus in Arabidopsis thaliana that confers tolerance to tobacco ringspot nepovirus. Mol. Plant-Microbe Interact. 9:729-735.

Leister, R. T., Ausubel, F. M., and Katagari, F. M. 1996. Molecular recognition of pathogen attack occurs inside of plant cells in plant disease resistance specified by the Arabidopsis genes RPS2 and RPM1. Proc. Natl. Acad. Sci. USA 93:15497-15502.

Lister, C., and Dean, C. 1993. Recombinant inbred lines for mapping RFLP and phenotypic markers in Arabidopsis thaliana. Plant J. 4:745-750.

Liu, Y. G., Mitsukawa, N., Lister, C., Dean, C., and Whittier, R. F. 1996. Isolation and mapping of a new set of 129 RFLP markers in Arabidopsis thaliana using recombinant inbred lines. Plant J. 10:733-736.

Lozano, J. C., and Sequeira, L. 1970. Differentiation of races of Pseudomonas solanacearum by a leaf infiltration technique. Phytopathology 60:833-838.

Marenda, M., Brito, B., Callard, D., Genin, S., Barberis, P., Boucher, C., and Arlat, M. 1998. PrhA controls a novel regulatory pathway required for the specific induction of Ralstonia solanacearum hrp genes in the presence of plant cells. Mol. Microbiol. 27:437-454.

Mauch-Mani, B., and Slusarenko, A. J. 1993. Arabidopsis as a model host for studying plant-pathogen interactions. Trends Microbiol. $7: 265-270$
Murashige, T., and Skoog, F. 1962. A revised medium for rapid growth and bioassays with tobacco tissue cultures. Physiol. Plant. 15:473497.

Prentki, P., and Krish, H. M. 1984. In vitro insertional mutagenesis with a selectable DNA fragment. Gene 29:303-313.

Prior, P., Steva, H., and Cadet, P. 1990. Aggressiveness of strains of Pseudomonas solanacearum from the French West Indies (Martinique and Guadeloupe) on tomato. Plant Dis. 74:962-965.

Rosqvist, R., Hakansson, S., Forsberg, A. A., and Wolf-Watz, H. 1995. Functional conservation of the secretion and translocation machinery for virulence proteins of yersiniae, salmonellae and shigellae. EMBO J. 14:4187-4195.

Saghai-Maroof, M. A., Soliman, K. M., Jorgensen, R. A., and Allard, R. W. 1984. Ribosomal DNA spacer-length polymorphisms in barley: Mendelian inheritance, chromosomal location, and population dynamics. Proc. Natl. Acad. Sci. USA 81:8014-8018.

Schell, M. A., Denny, T. P., and Huang, J. 1994. Extracellular virulence factors of Pseudomonas solanacearum: Role in disease and their regulation. Pages 311-324 in: Molecular Mechanisms of Bacterial Virulence. C. I. Kado and J. H. Crosa, eds. Kluwer Academic Pub., Dordrecht, The Netherlands.

Schmit, J. 1978. Microscopic study of early stages of infection by Pseudomonas solanacearum E.F.S. on "in vitro" grown tomato seedlings. Pages 841-856 in: Proc. Int. Conf. Plant Pathol. Bacteriol., Station de Pathologie Végétale et Phytobactériologie, 4th. INRA eds.

Scofield, S. R., Tobias, C. M., Rathjen, J. P., Chang J. H., Lavelle, D. T., Michelmore, R. W., and Staskawicz, B. J. 1996. Molecular basis of gene-for-gene specificity in bacterial speck disease of tomato. Science 274:2063-2065

Sharma, S., and Signer, E. 1990. Temporal and spatial regulation of the symbiotic genes of Rhizobium meliloti in planta revealed by transposon Tn5-gusA. Genes Dev. 4:344-356.

Sijmons, P. C., von Mende, N., and Grundler, F. M. W. 1994. Plantparasitic nematodes. Pages 685-704 in: Arabidopsis. E. M. Meyerowitz and C. R. Sommerville, eds. Cold Spring Harbor Laboratory, Cold Spring Harbor, NY

Stam, S. 1993. Construction of genetic linkage maps by means of a new computer package: JoinMap. Plant J. 3:739-744.

Tang, X., Frederick, R. D., Zhou, J., Halterman, D. A., Jia, Y., and Martin, G. B. 1996. Initiation of plant disease resistance by physical interaction of AvrPto and Pto kinase. Science 274:2060-2063.

Thoquet, P., Olivier, J., Sperisen, C., Rogowsky, P., Laterrot, H., and Grimsley, N. 1996a. Quantitative trait loci determining resistance to bacterial wilt in tomato cultivar Hawaii7996. Mol. Plant-Microbe Interact. 9:826-836.

Thoquet, P., Olivier, J., Sperisen, C., Rogowsky, P., Prior, P., Anaïs, G., Mangin, B., Bazin, B., Nazer, R., and Grimsley, N. 1996b. Polygenic resistance of tomato plants to bacterial wilt in the French West Indies. Mol. Plant-Microbe Interact. 9:837-842.

Van den Ackerveken, G., Marois, E., and Bonas, U. 1996. Recognition of the bacterial avirulence protein AvrBs3 occurs inside of the host plant cell. Cell 87:1307-1316.

Van Gijsegem, F., Genin, S., and Boucher, C. 1993. Evolutionary conservation of pathogenicity determinants among plant and animal pathogenic bacteria. Trends Microbiol. 1:175-180.

Van Gijsegem, F., Gough, C., Zischek, C., Niqueux, E., Arlat, M., Genin, S., Barberis, P., German, S., Castello, P., and Boucher, C. 1995. The hrp gene cluster of Pseudomonas solanacearum, which controls the production of a type III secretion system, encodes eight proteins related to components of the bacterial flagellar biogenesis complex. Mol. Microbiol. 15:1095-1114.

Vasse, J., Frey, P., and Trigalet, A. 1995. Microscopic studies of intercellular infection and protoxylem invasion of tomato roots by Pseudomonas solanacearum. Mol. Plant-Microbe Interact. 8:241251.

Wolter, M., Hollricher, K., Salamini, F., and Schulze-Lefert, P. 1993. The mlo resistance alleles to powdery mildew infection in barley trigger a developmentally controlled defence mimic phenotype. Mol. Gen. Genet. 239:122-128.

Yabuuchi, E., Kosako, Y., Yano, I., Hotta, H., and Nishiuki, Y. 1995. Transfer of two Burkholderia and an Acaligenes species to Ralstonia gen. nov.: Proposal of Ralstonia pickettii (Ralston, Palleroni and Duodoroff 1973. comb. nov. and Ralstonia eutropha (Davis 1969) comb. nov. Microbiol. Immunol. 39:897-904. 